\title{
宮中能楽場からみた能楽堂の近代化について THE MODERNIZATION OF NOH THEATER THROUGH THE IMPERIAL COURT NOHGAKUJO
}

\author{
奥 富 利 幸* \\ Toshiyuki OKUTOMI
}

\begin{abstract}
In this paper, I will analyze the construction and character of the Imperial Court Nohgakujo. The theater, designed by Katayama Toukuma, was built in 1915 for Emperor Taisho's accession ceremony, and was dismantled the following year. It can be said that this represents the first case in which the Noh performance space manifests as a theater proper. This is extremely important when we think about the modernization of the Noh theater. It is at the Imperial Court Nohgakujo, where for the first time, Western-style benches were introduced to the auditorium and the Noh stage was brought to the interior in the building. In this paper, I describe the style of the new Noh theater. After the Imperial Court Nohgakujo was disassembled, it was later reconstructed on a site at Peers' Club. The theater was in continual use as an important Noh theater during royal visits. Using this example, I will illucidate the transfer from the Noh space to the Noh theater, the process of modernization of the Noh space.
\end{abstract}

Keywords: Imperial Court, Noh Theater, Katayama Toukuma, Peers' Club, Taisho Emperor 宮中, 能楽堂, 片山東熊, 華族会館, 大正天皇

1.はじめに

本論では、大正天皇の御大典での演能のために皇居内に建設さ れた宮中能楽場について、その特色と使われ方、近代の能楽堂に おける歴史的意義を明らかにする。宮中能楽場は、宮内省内匠䄅 の片山東熊 1 の設計で、1915 年 (大正 4 ） 12 月 7、8 日の大正天 皇御大典での演能に備えて、同年 10 月に宮城内に竣工した能楽 堂である。翌年には解体されており、短期に存在した言わば幻の 能楽堂である。しかしながら、宮中能楽場は、新しい試みが実施 されたことにより、能楽堂の近代化を考える上で極めて重要な作 品である。つまり、新しい試みとは、初めて見所に椅子を導入し たり、能舞台を室内に入れる入れ子とした点である。そうした能 楽堂の新しい様式に関しての検証を行う。また、この宮中能楽場 は、解体された後に華族会館に移築されており、移築後も大正天 皇の行幸能が行われるなど、皇室との係わりを保ちながら、依然 として重要な能楽堂として使用され続けた。本論では、こうした 事例についても言及して、宮中能楽場が近代能楽堂として担った 役割について解明したい。

\section{2. 宮中能楽場の位置と構成}

宮中能楽場は、皇居の表宮殿内の二重橋を渡って正面の御車寄 とその背後の正殿との間の中庭に建設された。正殿は、元旦の朝 賀や憲法の発布式などを行う宮中の主要な儀式場であるが、その 前庭である中庭に能楽場が建設されたのである。この配置は、京 都御所での正殿である紫宸殿の正面南庭に能舞台が設えられた 形式と同様である。つまり、紫宸殿前では、能舞台であったが、 このときは見所を併設した能楽場が正殿前に建てられた。したが って、正殿から天皇や来賓が能を御覧になった伝統的な配置構成 がこの宮中能楽場にも踏襲されたことになる。
宮中能楽場については、当時の状況を記録した新聞や文献資料 から、その概要を確認してみたい。新聞記事として、「東京朝日 新聞」、「中外商業新報」、文献資料として、池内信嘉『能楽盛衰 記下巻・東京の能』、十二世梅若万三郎『能楽随想 亀堂閑話』 などを取り上げて、宮中能楽堂に関する記録を抽出してみたい。 「東京朝日新聞」 1915 年（大正 4 年）8月 14 日

・千余名の陪覽席

・ 木造宮殿風建築

・垔鉛鉄板莫屋根

- 大正 4 年 10 月上旬拨工予定

・御廊下と正殿との間の御広庭に建設

- 広さ約 200 坪、左右に 114 坪の入側廊下を設けて正殿と連接

・大廊下の脇に 18 坪の能舞台

・大廊下に鏡の間や楽屋

・北側に一段高く天皇と皇后陛下の玉座

・玉座に並び、皇族席を南面して設置

・前面に一般臣下の陪覧席

この記事により、能楽堂の規模や外観の様子、能舞台と楽屋の 位置、見所の配置が分かる。

「東京日日新聞」 1915 年（大正 4 年） 12 月 7 日

- 宮中大夜会として、豊明殿での祝宴後に午後 8 時より能楽天覧 を実施

この記事により、夜会は豊明殿での祝宴後に実施されたことが分 かる。

池内信嘉『能楽盛衰記下巻・東京の能』, 能楽会, 1925 年（大正 14 年)

・御覧所と陪覧席は豊明殿の廊下から取付けて新築

・御覧所は一段高い所に設置 
・見所の雅壇は悉く緋毛氈敷

・天井は花丸を描いた格天井

・御覧所の両側に皇族席

・元老、大臣、文武官が陪覧

・舞台前の天井に大電灯、少しの陰影もなく足元まで明るい

この記事により、能楽堂の床仕上げや御覧所の設置位置、照明 の状況がわかる。記述の中に豊明殿の廊下は正殿の廊下のことで あろう。何故なら、12月 7 日の東京日日新聞の記述のように、 豊明殿では祝宴が行われていたため、そこから、演能の準備の整 った正殿に移って、天覧能が実施されたと考えるのが妥当である。 十二世梅若万三郎『能楽随想 亀堂閑話』, 玉川大学出版社, 1997 年 (平成 9 年)

- 12 月 $7 、 8$ 日に、皇族、文武官、外国使臣等二千余名が能楽堂 に参集

・能楽堂は豊明殿前の中庭に設置

・能楽堂の総建坪 200 坪

・内部の壁に洋風唐草模様の赤色壁紙を貼る

・床に赤い絨庮を敷く

- 天井は格天井で裏板に五色の花丸を描き、宮内省内匠寮の都筑 真琴の揮毫

・舞台は 18 坪の総桧造、木兽御用材で造営

・舞台設計は内匠寮の安藤技手が担任

・舞台は三間四方で正面に階、周囲に白州がある

- 舞台下に 6 個、後座に 2 個、橋掛かりに 4 個の鷕がある

・橋がかりの長さは二間

・鏡板松は小堀䩡音の揮毫

・舞台は後に華族会館に下賜された

この記述では、 $7 ， 8$ 日の両日に能楽堂に 2 千人が集まったと され、東京朝日新聞の千余名の陪覧席が裏付けられた。また、能 楽堂内部に洋風の赤い壁紙が貼られていたことが分かる。さらに、 床の赤い毛氈と格天井の花丸は池内信嘉の能楽盛衰記の記述と 一致する。また、能楽師らしく、能舞台の記述が詳細である。ま ず、能舞台の担当は、安藤技手とあるので、宮内省内匠寮技手の 安藤永次郎 2 が担当したものと考えられる。能舞台は、定式の三 間四方で、舞台下に䍜が 12 個埋けられ、橋挂かりの間数は二間 とあるが、二閒は特殊であるため疑問が残る。鏡板の作者は、皇 室を題材とした日本画で知られる小堀鞆音である。

「中外商業新報」 1916 年（大正 5 年）8月 7 日

・能楽場の取壊し開始

・能楽場は破風造りで 327 坪

・華族会館に下賜

- 内匠寮の馬場内匠頭、高橋事務官監督の下で、安藤宮内技手主 任が担当

・工期は 6 日に着手して、約一ヶ月の予定

・材料は全て大手門内に運ばれ、華族会館に引渡す

この記事により、能楽場の解体が 1916 年 8 月 6 日から一ヶ月 の予定で、能舞台の造営に携わった安藤技手の担当で行われたこ とが分かる。解体された材料は、大手門内に運ばれ、そこから華 族会館に引渡された。
以上の記事をまとめると、能楽場は、次のような概要であった ことが分かる。

つまり、能楽場は、御大典が行われた大正 4 年の 10 月上旬頃 に拨工した。広さは約 200 坪で、左右に 114 坪の入側廊下を設け て正殿と連接した。収容人員は千名程度である。

見所は、天皇と皇后の御覧所とその両側に皇族席を正殿廊下に 取付けて一段高い所に設けられた。そこから、元老、各大臣、文 官、武官用の陪覧席が順次配置された。床は全て緋毛氈が敷かれ ており、壁には、唐草模様の赤色の壁紙が貼られ、天井は格天井 で、裹板の花丸が宮内省内匠寮の都筑真琴の揮毫で描かれた。天 井には大照明が設置された。

能舞台は、内匠寮の安藤技手の設計で設けられた。能舞台の広 さは、約 18 坪で御車寄の大廊下を背にして建てられ、鏡の間と 楽屋は大廊下に設置された。能舞台の仕様は、木兽御料林の桧を 使った総桧造で、三間四方の広さで正面に階が付けられた。周囲 には白州が配された。鏡板の老松は小堀鞆音の揮毫で描かれた。 舞台の床下には舊が埋けられ、舞台下に 6 個、後座下に 2 個、橋 掛かり下に 4 個、合せて 12 個が埋けられた。

外観は、宮殿風で破風造屋根の亜鉛鉄板草であった。

こうした能楽場の状況は、内部を写した 1 枚の写真で確認でき る。つまり、木子文庫に残されている内観写真 ${ }^{3}$ と『建築雑誌』4 に揭載された写真 (写真 1 ) である。この 2 枚の写真を比心゙ると まったく同じ構図であることから、同じフィルムから焼かれたも のと考えられる。

この写真から、先ほどの新聞記事や文献資料で紹介された内容 が、現場をかなり忠実に描写していたことが分かる。また、この 写真により、次の点が新たに確認できる。

・見所観覧席はベンチ形の椅子である

・能楽場は能舞台を中心に左右対称形の平面である

・雛壇は能舞台から3 方に均一に設置された

・橋掛かりは 3 間である

・天井折上格天井で、そこからシャンデリアが下がる

・能舞台正面前方天井に 2 つの大きなトップライトがある この写真からの情報により、能楽場内部の空間構成について、 基本的な様子が確認できた。



写真 1 宮中能楽場内観写真（『建築雑誌』第 31 巻 372 号) 


\section{3. 宮中能楽場における近代化}

以上の宮中能楽場の分析により、次の点でそれまでの能楽堂と は異なる試みがなされていたことが分かる。

・見所を全て毛暨敷きの雊壇として、椅子席にしている

・見所を室内化して、能舞台を入れ子で納めて、シャンデリア照 明とトップライトを併用している

・能舞台と御覧所を結ぶ線を中軸として、左右対称形の見所空間 を構成している。

まず、それまでの能楽堂の見所は妌席の床座であり、入口で下 足を脱いで入場する。しかし、ここでは能楽堂として初めて、椅 子式として、下足で入場できるようになった。

次に、能舞台が室内に入り、入れ子式となったことである。こ れも新しい試みで、そのために、能舞台への採光をトップライト で補い、照明には、洋風のシャンデリアを吊り下げている。

また、従来の能楽堂では、見所が橋撕かり側で広く取られるの が常套であるが、ここでは、見所が能舞台の中軸線で左右対称の 空間構成としている。

以上の試みの中で、椅子式については、青山御所の能舞台で既 に明治天皇は椅子で能を御覧になっているが5、続いて建設され た能楽社では、御覧所とは別に一般席が杵席となっており、この 形式は、その後の能楽堂に継承された。したがって、天皇の御覧 所以外の一般席に椅子席を設けたことは、皇室における近代化が 見所にも波及したようにも見えるが、実はその背景として、梅若 万三郎の『亀堂閑話』でも記述されたとおり、この能楽堂には、 外国貴賓も招待されていたため、むしろそのために、椅子席にす る必然性があったのである。こうした外国貴賓に配慮したことは、 池内信嘉の『能楽盛衰記』で、外国貴賓の陪観の淮備として、祝 宴御能の番組を外国語に翻訳することの苦労話が紹介されてい る。

また、この能楽堂は、宮内省内匠寮の片山東熊と安藤永次郎が 中心となって設計されたものと考えられるが、東京朝日新聞に記 載された「木造宮殿風建築」とあるように、基本的には当時の明 治宮殿の様式が踏襲されていたという見方ができる。この能楽場 が接続された正殿では折上げ格天井にシャンデリアが吊るされ ており、床の䋐㲎炎敷も能楽場と同様である。椅子式で執り行われ た儀式に適合した高い天井の大空間の木造建造物は既に明治宮 殿で造営されていたのである。したがって、その正面に造営され た能楽堂がその建築様式を踏襲することはむしろ必然の結果で あったのではないか。そして、能舞台が室内に入る入れ子式は、 それまでの能楽堂の概念を根本的に変える大きな試みであった。 しかし、能舞台を正殿側の御覧所と向い合わせ、その軸線の左右 対称に見所を配置することは、従来の能楽堂のやり方ではなく、 むしろ紫宸殿前に能舞台を設えた宫中伝統の配置構成である。し たがって、この点においては、宮中能楽場は近代化と伝統を融合 させた能楽堂とみることができよう。

\section{4．宮中能楽場の解体と華族会館への下賜}

御大典能が終わると、内匠寮の馬場内匠頭と高橋事務官の監督 下で安藤技手の指揮のもと、翌年の 1916 年（大正 5) 8 月 6 日
から能楽場の解体が始まった。下賜先である華族会館に引き渡す ため、解体された能舞台は全て大手門内に運搬された。当時の華 族会館は、コンドルが設計した旧鹿鳴館で、移筑後もこの能舞台 は行幸能や外国貴賓供応能に使われることになった。

能舞台は、1916 年 (大正 5 年) 5 月に移転費 8 千円を添えて、 華族会館に下賜され、翌年の 1917 年（大正 6 年） 4 月に竣工し た。下賜の経緯は不明であるが、明治初期に能楽の復興拠点とな った能楽社が、皇室の㕡虜と岩倉具視の構想で、華族が中心とな って建てられたことや、明治天皇の華族邸宅行幸に必ず能が上演 され、能楽を介して、皇室と華族の交流が、明治期を通して行わ れたことを考慮すると、この能舞台が、華族会館に下賜されたこ とは、当然の成り行きとも考えられる。

華族会館に移築された能舞台は、見所の建物とは別に、独立し て建てられた。当時の配置図6によれば、本館の東隣に日本館が あり、その脇に設置されている。能舞台は西側に向けて設置し、 台覧席を設えた建物が、能舞台の正面に東側に向いて建ち、仮設 と思われる陪覧席が脇正面と地裏側に設置されている。

華族会館での能舞台の様子は、1917 年（大正 6 年）5月 19 日 「東京日日新聞」で「華族会館の能楽堂」として掲載している。 掲載された写真によれば、能舞台の脇正面側に大きく白州を配し、 白州の向こうに日本館の建物が見える。御覧所の天井は格天井、 台覧席の上部が折上格天井となっており、その中心に照明器具が 取り付いている。

また、他の資料では『米賓歓迎会記念写真帖』7の中に、「ヴァ ンダーリップ氏一行歓迎晚餐会 大正 9 年 4 月 25 日華族会館」 に揭載された「ヴァンダーリップ氏ノ答辞」(写真 2 ) と「能楽」 (写真 3 ) で確認できる。「ヴァンダーリップ氏ノ答辞」は、御 覧所を能舞台の方から撮影したもので、ヴァンダーリップ氏が縁 側に立って、椅子に座った観客に話をしているが、この写真で注 意すべき点は、御覧所の屋根と能舞台の屋根の間がトップライト のような斜めの屋根で覆われていること、また、縁側の高さは、 この御覧所が椅子席を前提に設計されているため、低くなってい ることである。また、「能楽」では、能舞台を脇正面側の斜め前 から撮影したもので、脇正面の白州の上には、シートで覆われた ような仮設の屋根が確認できる。したがって、この写真が撮影さ れた、1920 年（大正 9 年） 4 月 25 日の時点で、白州は、仮設の



写真 2 ヴァンダーリップ氏ノ答辞（華族会館見所） 『米資歓迎会記念写真帖』大正 9 年 
屋根で覆われていたことがわかる。つまり、元々、入れ子で設計 された能舞台は、華族会館に移されて、見所が独立した建物とな り、その結果、能舞台周辺の白州の野天は、再び仮設の屋根で覆 われたという経過をたどった。

\section{5，華族会館能楽堂での大正天皇行幸能}

こうして宮中能楽堂から能舞台が移築された華族会館能楽堂 では、宮中より下賜された能舞台の舞台開に合わせて、行幸能が 行われた。1917年（大正 6 年）5 月 22 日の行幸では、天皇の他 に、皇后、東宮、淳宮、高松宮、東伏見宮、伏見宮、同妃の台臨 があった。当日の日程8 8 次の通りであり、拝謁を除けば、能楽 三昧の行幸であったことが伺える。

. 午前 10 時 御出門

- 午前 10 時 15 分 着御

. 午前 10 時 20 分 10 時 35 分（15 分）拝謁

. 午前 10 時 40 分 11 時 50 分（1 時間 10 分）能：弓八幡

. 午前 10 時 50 分 12 時 10 分 (20 分) 狂言：棒しばり

. 午前 12 時 15 分 入御

- 午前 12 時 30 分 午後 1 時 45 分（1 時間 20 分）御食事

. 午後 1 時 55 分 出御

. 午後 2 時 $~ 3$ 時 10 分（1 時間 10 分）能:雲雀山

. 午後 3 時 10 分 3 時 30 分 (20 分) 御休息

. 午後 3 時 30 分 4 時 5 分 (35 分) 一調、仕舞

. 午後 4 時 5 分 $\sim 5$ 時 5 分 (1 時間) 能: 夜討曽我

. 午後 5 時 5 分 $\sim 5$ 時 15 分 御休息

- 午後 5 時 15 分 還御

当日の会場配置図（図 1) によれば、本館前に、陪覧者のための 臨時食堂と楽隊の待機所が設営された。また、能楽堂では、脇正 面側と地裏側に陪覧席が設置されている。また、本館の内部は 2 階が主な控室になっており、南側正面真中に食堂があり、その西
隣の南西角部屋に東宮、皇子、皇族の御休所となり、その北隣に 皇族附御用保の部屋がある。また、食堂の東隣の南東角部屋には、 部屋名の記載がなく、その北隣が皇后宮の御休所になっている。 したがって、部屋名のない南東角部屋が、天皇の御休所、つまり、 便殿に充てられたものと考えられる。因みに華族会館によって作 成された「天皇陛下、皇后陛下行幸行啓御次第」9によれば、「一 館長御先導階上便殿二入御」とあり、2 階に便殿が置かれたこと は間違いなく、そうすると南東角部屋以外に使うことができる部 屋は他に見当たらない。したがって、拝謁は便殿にて行われ、そ の後に能楽御覧という次第であったと考えられる。天皇より一足 先に陪覽者が入場 10 し、その後に天皇が館舆の先導で出御となる。 本館から能楽堂への経路は、当日の検討図11により、本館から日 本館を経由して、能楽御覧所に出御したことがわかる。また、同 図には、玉座周りの座配も記録されており、御覧所中央の台覧席 には、天皇と皇后が並んで座るように椅子とテーブルが設置され、 その左右に特別席が設けられている。舞台に向かって、右側に、 東宮、皇子殿下、左側に皇族が着座された。また、その特別席の 両側、左側に内大臣、侍従長、武官長、侍従、侍医、東宮職、書 記官、評議員、供奉員など、右側に館長、評議員、供奉員などが 座している。つまり、台覧席の左側が宮中関係者で、右側が華族 会館の関倸者という座配であったことが分かる。また、脇正面側 と地裏側の座配は不明であるが、主だった陪覧者は、母屋である 御覧所に着席し、その他の陪覧者が、脇正面と地裹側に回ったも のと考えられる。天覧能の座配に関する資料は少なく、たいんん 貴重な記録である。

また、当日の陪覧者に宛てられた案内状 12 によれば、「一當 日管員一同倍覧ノ筈二候得共場内手挟二付御不満足ノ點有之候 哉モ難斗侯二付豫义御断申上置候」とあり、会場が手狭のために、 招待者の全てが能楽を陪覧できたわけではないことが伺える。こ の件に関しては、新聞 13 にも、「曾員は、赤、白、青、樺の等の

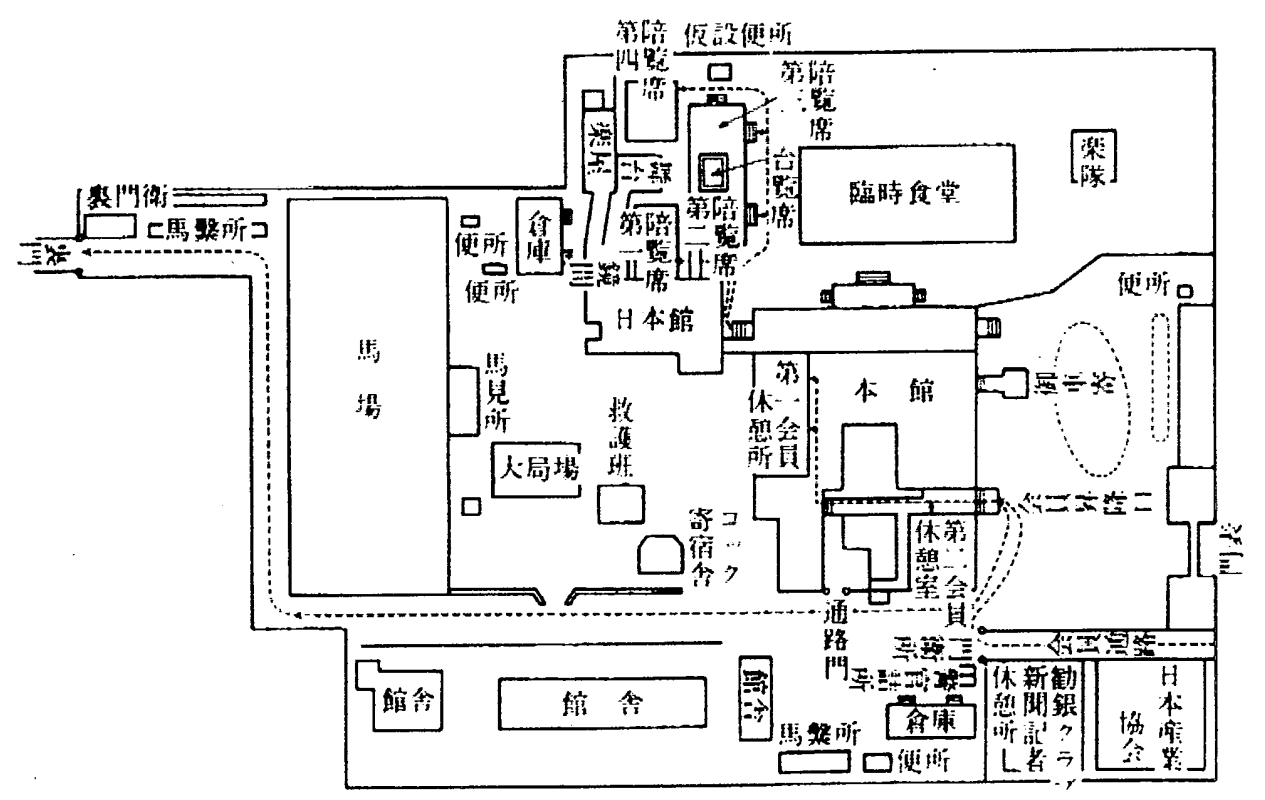

図 1 華族会館配置図 『華族会館の百年』昭和 52 年 
陪覧券に依って指定の席に着く。」とあり、華族の中での序列に より、陪覽者と座配が決められていたことが分かる。また、服装 に関して、次のような記述がある。「一當日御服装ハ「シルク ハット」「フロックコート」又制服アルモノ八之ニ相當スル服装 ノ事」つまり、洋装が基本であり、帽子もかぶって出席すること が要請されていたことがわかる。伝統芸能の観覧と洋装の取り合 わせは、奇妙にも思えるが、当時の世相として、フォーマルな服 装として、洋装が意識されていたことが分かる。

このように、宮中能楽堂から華族会館に移された能舞台は、入 れ子式から能舞台と見所が対置する形式に変更されたが、この背 景には、明治期からの行幸における能楽御覧所の影響があったも のと考えられる。つまり、この能舞台の舞台開で天皇行幸による 天覧能があったように、移築する段階で、将来、天皇が行幸する ことは当然、予測されていたものと考えられる。また、宮中能楽 場では、外国貴賓を招く国家の最重要行事であったから、壮震な 能楽堂が求められたが、下賜を受けた華族会館では、むしろ、天 皇行幸の方に関心があったものと考えられる。したがって、大き な入れ子式の能楽堂をそのまま移す必要はなく、むしろ、明治天 皇の能楽御覧所として用いられた能舞台と御覧所が白州を介し て対置する形式が順当であったのであるう。しかし、能舞台と対 置する御覧所も伝統的な形式とは異なる点があった。それは、雊 壇形の客席である。通常の対置式の広間は、基本的に和室であり、 青山御所能舞台の御覽所のように、床に絨掞を敷き詰めて椅子を 置いたが、この華族会館能楽堂では、絨琰敷でも、雛壇となって いる。そのため、前面の縁側もその関係で低くなっていることが わかる。また、華族会館能楽堂の見所に置かれているべンチ形の 長椅子は、写真で見る限り、宮中能楽堂で使われたものと一致し ており、建物之一緒に持ってこられた可能性が高い。したがって、 華族会館能楽堂では、入れ子形式の能楽堂でなく、能舞台と見所 が対置する形式になったが、単に明治期の天皇行幸能の御覧所を そのまま継承したものではなく、宮中能楽場の新しい形式を融合 した能楽堂となったのである。

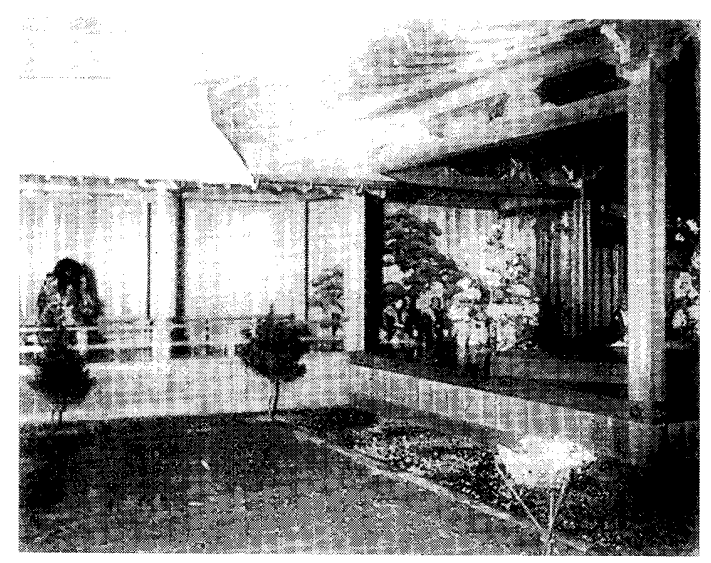

写真 3 能楽 (華族会館能舞台) 『米䆩歓迎会記念写真帖』大正 9 年

\section{6. まとめ}

以上のように、宮中能楽堂は、外国貴賓を供応することを前提 として造られた能楽堂であった。そして、その源流となるのは、
明治期以降に推進されてきた、外国貴賓供応芸能としての能楽の 役割 14 と能楽堂の近代化であり、こうした一連の変遷のなかで、 能楽堂を飛躍的に近代化させたのが宮中能楽場であった。また、 そうした近代化を取り入れた一方で、依然として、宮中の伝統で ある正殿と能舞台の配置構成や宮殿建築の要素を加味している。 さらに、伝統と近代化の諸条件をまとめ上げた設計者である片山 東熊の手腕によるところも大きかった。つまり、宮中能楽場では、 近代化の諸条件を充たすべく、大空間の入れ子式、椅子式の騅壇、 トップライト、シャンデリアなどの新しい試みを投入し、一つの 模範事例を示したのである。したがって、この能楽場は、単に外 国貴賓供応のためというだけではなく、皇室の伝統、明治以来の 皇室と能楽の近代化を総括した建物であった。また、この宮中能 楽場の造られた理由は、大正天皇の御大典という、日本の新しい 天皇を国内外に知らしめる国家行事に供応芸能を提供するため であったが、それは同時に、能楽が外国貴賓供応芸能として、正 式に位置づけられたことを示寸行事でもあった。したがって、こ の宮中能楽堂が、正統な能楽堂の雛形として、社会的に認知され る機会になったのは確かである。この宮中能楽場がその後の能楽 堂に与えた影響に関しても、今後の検証課題として重要である。

\section{注}

${ }^{1}$ 片山東熊 : 御大典造営では、宮中能楽場の他、京都御所第一朝 集所、春興殿を担当する。

2 十二世梅若万三郎『能楽随想 亀堂閑話』、「御舞台は十八坪、 総桧造でございまして御用材は木曽の御料林からで、御設計は、 やはり内匠寮の安藤さんとおつしやる御方が御担任なさいま したと承つてをります。」安藤永次郎は宮内省内匠寮技手で、 後年に沼津御用邸などを担当。

3 「木子文庫」(東京都立図書館所蔵) 木 187-061 大正天皇御大礼 の際の皇居正殿仮設能舞台写真

4 『建築雑誌』第 31 巻 372 号 1917 年（大正 6 年） 12 月宮中能 楽場（大正四年竣工）故正員 工学博士 片山東熊君作物

5 奥冨利幸「明治初期における能楽堂誕生の経緯一青山御所能舞 台、能楽社の建設を通して」日本建築学会計画系論文集, 第 565 号, pp337 342, 2003 年 3 月

${ }^{6}$ 大正 6 年 5 月 22 日行幸の時の本館使用配置図『華族会館の百年』 昭和 52 年 12 月、社団法人霞会館編纂 $\mathrm{p} 114$

7 『米賓歓迎会記念写真帖』発行者や発行年は不明。大正 9 年の 日付が目次の各タイトルの下に掲載されているため、その頃に 発行されたものと見られる。東京大学総合図書館蔵

${ }^{8}$ 水野勝邦「たびたびの行幸」『華族会館の百年】昭和 52 年 12 月、 社団法人霞会館編纂 $\mathrm{p} 112$

9 「天皇陛下、皇后陛下行幸行啓御次第」, 華族会館『自大正六年 五月 至大正十年十月 本館分館行幸啓関係書類』所収 霞会 館所藏

10 華族会館『自大正六年五月 至大正十年十月 本館分館行幸啓 関係書類』によれば、「一 会員一同能楽倍覧場二入ル 午前 十時二十分 - 館長御先導能楽御覧所二 出御 能楽開始 午前十時四十分」とある。

11 華族会館『自大正六年五月 至大正十年十月 本館分館行幸啓 関係書類』所收 霞会館所藏 座配の記録もあり

12 華族会館『自大正六年五月 至大正十年十月 本館分館行幸啓 関係書類』所収 霞会館所藏「大正六年五月十七日 華族会 館長 公爵 徳川家達」より通知されている。

${ }^{13} 1917$ 年（大正 6 年） 5 月 19 日の東京日日新聞「けふの御幸」 14 岩倉具視が特命全権大使として欧米巡遊の際に、欧米でのオぺ ラを観覽し、日本における供応芸能の必要性を痛感して、能楽の 復興と能楽堂の整備をした。（前掲 注 5)

（2007年 3 月 10 日原稿受理， 2007 年 5 月 28 日採用決定 